\title{
Effect of learning approaches of pre-service science teachers on the argument create skills
}

\author{
Nilay Aydogan ${ }^{1 a}$, Huseyin Polat ${ }^{1}$, Ozlem Cankaya ${ }^{1}$, and Fatma Bilge Emre ${ }^{1,2}$ \\ ${ }^{1}$ Department of Mathematics and Sciences Education, Faculty of Education, İnönü University, \\ 44280 Malatya, Turkey \\ ${ }^{2}$ Prof. Dr. Hikmet SAYILKAN Advanced Materials Research an Application Laboratory \\ Scientific and Technological Research Centre, İnönü University, 44280 Malatya, Turkey
}

\begin{abstract}
The aim of this study is to investigate the relationship between science teacher candidates' ability to construct an argument and learning approaches. For this purpose, the "Learning Approach Scale" was applied to Inonu University Educational Faculty Science teachers 'first grade students', and the results were compared with the arguments which were created by the same students. The findings shows that there is a significant relationship between their argument create skills and learning approaches.
\end{abstract}

Keywords: Argument Create Skills, Learning Approach, Science Education, Pre-Service Science Teachers

\section{Introduction}

In recent years, student-centered teaching theories in which students research and find or create more systematic information by processing raw information, have been attracting attention as an alternative to the teaching methods currently available in science teaching [1]. One of these methods that serve this purpose is the method of argumentation. Argumentation is defined as scientific discussions aimed at defending or refuting a thought [2].

According to Toulmin [3], the argumentation concept is defined as a coordination of the theories and evidence to support or refute an explanatory result, model or prediction. Argumentation can be expressed as the process of put out claims to solve a problem situation and proving the rightness of ideas to the other side by putting more reasons supporting those claims [4].

It was observed that, the argumentation method, which is mentioned more frequently in science education in the world and in Turkey than in other fields, has developed

${ }^{a}$ Corresponding author: nilay.aydogan@inonu.edu.tr 
students' academic achievement, critical thinking, problem solving and decision making skills, and the argumentation process is affected by peer education [5, 6, 7, 8, 9].

The development of scientific literacy levels is one of the goals of science education. It is expected that the individuals with high scientific literacy levels also have high ability to create an argument [10]. In this light, the level of argument create ability of the teachers is very important in science education.

Concepts of superficial and deep learning approaches have been put forward in studies on how students perceive a particular reading part and how they engage in learning [11].

Deep learning approach has been defined as willingness to learn, , intense and critical interaction with content, linking previous knowledge with new learnings, associating concepts with daily experiences, establishing a relationship between events and outcomes and review the logic of the subject and the superficial learning approach also defined as the tendency to complete the tasks required by the job, to memorize the necessary information in the exams, not to distinguish the principles from the examples, to view the learning work as external loading, to focus on individual items without integrity and tendency to do not explore goals and strategies [12].

Learning habits are related to the use of learning strategies and appropriate strategies by students. Motivation points to why the students want to learn, and strategy is how to learn [13].

\section{Method}

The universe of the research is constituted by 1st grade students of İnönü University, Faculty of Education Science Teacher Education. In the sample, there are pre-service teachers participating in classes to represent the class level. 48 students attending the first grade of the Science Teacher Training Program participated in the research.

\subsection{Data collection tool}

In order to determine the learning approaches of the pre-service teachers, "Learning Approach Scale (LAS)" developed by Ellez and Sezgin [14] were used. 5-Likert-type scale with 30 items, have "I totally agree", "I agree", "Undecided", "I do not agree", "I do not fully agree" options. The Cronbach Alpha reliability coefficient of the scale is 0.81 and the items in the measure are in two dimensions. These dimensions are called the "Deep Approach (DA)" and "Superficial Approach (SA)". There are 19 items in the dimension of deep approach and 11 items in the aspect of the superficial approach. The items in the scale were scored as 5, 4, 3, 2, 1 starting from the "I totally agree" option. The reliability coefficients of the subscales of the scale are 0.82 and 0.76 . Subscale definitions are given in Table 1 [15].

Table 1. Subscale definitions of LAS

\begin{tabular}{cl}
\hline \multicolumn{1}{c}{ Subscales } & \multicolumn{1}{c}{ Definition } \\
\hline \multirow{3}{*}{ Deep Approach (DA) } & Actively participating in the lesson, asking questions \\
& actively during learning, trying to understand learning \\
& materials, linking previous knowledge with new ones, \\
& linking what they learn with everyday life, learning to \\
& learn, not satisfied with what they learn in the lesson, \\
& researching knowledge from different sources, actively \\
participating in the lesson
\end{tabular}


An argument-based science learning report which was developed by using rubrics used by Choi [16] was used to determine pre-service teachers' argument create skills. The arguments they made were evaluated by 8 teaching staff and $\mathrm{PhD}$ students as the quality of the arguments and descriptions they used in the reports and the total writing scores.

\section{Findings}

In this work, where the pre-service teachers' argument skills were evaluated, it was aimed to evaluate the existing arguments about acid-bases, to create arguments and to form counter arguments against existing arguments.

\subsection{Activity 1}

It was asked to pre-service teachers to evaluate an existing claim about global warming and support this claim with data. They were asked to score between 1 and 3 according to whether they participated in the evaluation or not. The following scale was used when this activity was scored.

Table 2. Activity evaluation scale

\begin{tabular}{cc}
\hline Criterion & Score \\
\hline Only Estimation & 1 \\
\hline Using Data & 2 \\
\hline Data and Justification & 3 \\
\hline
\end{tabular}

The highest score is 15 because there are 5 expressions in total. The average of the first event is 6.91. It is seen that pre-service teachers are able to evaluate the claims of the prospective teachers and support them at least in some cases.

\subsection{Activity 2}

In this activity, they were asked to evaluate and indicate the cause of an existing claim about the effects of acids on human health. The following scale was used when this activity was scored.

Table 3. Activity evaluation scale

\begin{tabular}{cc}
\hline Criterion & Score \\
\hline Only Estimation & 1 \\
\hline Using Data & 2 \\
\hline Data and Justification & 3
\end{tabular}

The highest score is 9 because there are 3 expressions in total. The average of the first event is 2.87 . This indicates that teachers are in the evaluation stage.

\subsection{Activity 3}

In this activity, it is requested to create claims about the effects of acids on human health and to support these claims with data. The difference between this activity and the other activities is that the pre-service teachers need to create and justify their own claims in the given issue. The following scale was used when this activity was scored. 
Table 4. Activity evaluation scale

\begin{tabular}{cc}
\hline Criterion & Score \\
\hline No Specific Claim & 1 \\
\hline Specific Claim & 2 \\
\hline Claim + Data & 3 \\
\hline Claim + Data + Justification & 4 \\
\hline Claim + Data + Justification + Supporting & 5 \\
\hline
\end{tabular}

The highest score is 5 in this activity. The average of the first event is 1.12 . This indicates that pre-service teachers can only create claims in a particular context, but cannot pass on the data phase.

\subsection{Activity 4}

In this activity there are 5 different expressions for evaluating the claims about acidbases. When one of these statements is evaluating, it is necessary to make a counter argument. The following scale was used when this activity was scored.

Table 5. Activity evaluation scale

\begin{tabular}{cc}
\hline Criterion & Score \\
\hline Using Only Data & 1 \\
\hline Data + Justification & 2 \\
\hline Data + Justification + Supporting & 3 \\
\hline Counter Claim + Data & 4 \\
\hline Counter Claim + Data + Supporting & 5 \\
\hline
\end{tabular}

The highest score to be awarded in the event is 17 . The average of this activity is 7.62. This suggests that the pre-service teachers can often use data to support their existing claims.

\subsection{The learning approaches of pre-service science teachers}

In order to determine the learning approaches of pre-service science teachers, the averages and standard deviations of the scores of the LAS' subscales were calculated. A t-test was conducted to determine whether the difference between the averages was significant. The results of the analysis are given in Table 6.

Table 6. The arithmetic mean, standard deviation results of LAS subscale scores of pre-service science teachers

\begin{tabular}{lccc}
\hline Subscales & n & A & SD \\
\hline Superficial Approach & 48 & 3,14 & 0,47 \\
\hline Deep Approach & 48 & 3,64 & 0,41 \\
\hline
\end{tabular}

When Table 6 is examined, it is seen that the average of the pre-service science teacher for the deep approach dimension $(\mathrm{O}=3.64)$ is higher than the mean of the superficial approach dimension $(\mathrm{O}=3.14)$. The difference between the averages of the two dimensions was significant, in favor of the deeper approach, according to the t-test results for the purpose of controlling $(\mathrm{p}<0,05)$. 
Table 7. Relationship between argument create skills and learning approaches

\begin{tabular}{lccc}
\hline & $\begin{array}{c}\text { Argument Create Skills } \\
\text { (ACS) }\end{array}$ & $\begin{array}{c}\text { Superficial Approach } \\
\text { (SA) }\end{array}$ & $\begin{array}{c}\text { Deep Approach } \\
\text { (DA) }\end{array}$ \\
\hline ACS - Pearson Correlation Coefficient & 1,00 & $-0,239$ & 0,462 \\
Level of Significance & - & 0,30 & 0,20 \\
$\mathrm{n}$ & 48 & 48 & 48 \\
\hline SA - Pearson Correlation Coefficient & $-0,239$ & 1,00 & $-0,36$ \\
Level of Significance & 0,30 & - & 0,00 \\
$\mathrm{n}$ & 48 & 48 & 48 \\
& & $-0,36$ & 1,00 \\
\hline DA - Pearson Correlation Coefficient & 0,462 & 0,00 & - \\
Level of Significance & 0,20 & 48 & 48 \\
$\mathrm{n}$ & 48 & & \\
\hline
\end{tabular}

As shown in Table 7, the relationship between pre-service science teachers' deep learning approach and their ability to create an argument is positive and the correlation coefficient is $r=0.462$. The calculated correlation coefficient was found to be significant at $\alpha=0,20$ level. Negative weak correlation was found between the superficial approach and the ability to create arguments.

\section{Discussion and conclusion}

Research and inquiry-based approaches include a range of purposes that serve scientific literacy, such as critical thinking, communication and linguistic skills development, and the gaining of scientific process skills. For this reason, argumentation which is one of the methods of inquiry and research based education, is considered as an effective tool in science education [17].

It is expected that a student who has started in university will have a high level of basic language usage skills such as reading, understanding, listening and speaking. The fact that the basic language skills are not at the desired level affects the learning of the students in the negative way and causes the behavior that is expected to occur in the students after higher education to not be realized at the desired level [18].

It has been shown that the learning approach influences the output of education, the superficial learning with the low level of learning output of and the deep learning are related to the high level of learning outcomes [19, 20, 21, 22], academic performance [23] and level of knowledge [12, 24].

One of the most challenged section for the students when they are creating their arguments is counter claim. It was observed that they were forced to find a claim against the claim they created. It is thought to have originated from the fact that they could not understand enough the claims they made.

It was also observed that students were having difficulty in generating data. It may be that they may not be able to fully remember the preliminary information about the cause or they may begin to write without using them. Moreover, it can be said that university students do not understand the importance and role of generating data when making a discussion [25].

Students with a deep learning approach have actively participate in the lesson, asking questions actively during learning, trying to understand learning materials, linking previous knowledge with new ones, linking what they have learned with everyday life, learning to learn, not satisfied with what they learn in the lesson, researching knowledge from different sources, actively participating in the lesson, properties. The results of our study show that students with a deeper learning approach have the ability to build higher arguments. These students can present data about the arguments they have formed and justify these data. They can reasonably support their 
claims about their arguments. However, they are not fully qualified to form a counter claim.

The learning approach of the students is not fixed and students can change their approach depending on the perception of the subject [26]. Students can be pushed to superficial learning when certain teaching and assessment strategies are used. However, it is not so easy to be guided to deep learning [27]. We think that by using various teaching methods, students will be able to improve their argument creating skills by directing them to deep learning. It is expected that the level of scientific literacy of the students who have the ability to set up arguments will also develop [28]. Thus, it is thought that the learning level of the future students of these pre-service teachers can be positively affected.

\section{References}

1. D. Karışan, Fen Bilgisi Öğretmen Adaylarının İklim Değişiminin Dünyamıza Etkileri Konusundaki Yazılı Argümantasyon Yeteneklerinin İncelenmesi (Yüksek Lisans Tezi).Yüzüncü Y1l Üniversitesi Fen Bilimleri Enstitüsü, Van (2011)

2. H. Polat, Atomun Yapısı Konusunda Argümantasyon Yönteminin İlköğretim 7. sınıf Öğrencileirinin Başarısı Üzerine Etkisi (Yüksek Lisans Tezi). İnönü Üniversitesi Eğitim Bilimleri Enstitüsü, Malatya (2014)

3. S. E. Toulmin, The Uses Of Argument, Oxford University Press, New York

4. S. Okumuş, 'Maddenin Halleri ve Isı' Ünitesinin Bilimsel Tartışma (argümantasyon) Modeli İle Öğretiminin Öğrenci Başarısına Ve Anlama Düzeylerine Etkisi (Yüksek Lisans Tezi). Karadeniz Teknik Üniversitesi Eğitim Bilimleri Enstitüsü, Trabzon (2012)

5. M. Felton, D. Kuhn, The development of argumentive discourse skills. Discourse Processes, 32, 135-153 (2001)

6. R. M. Gillies, A. Khan, Promoting reasoned argumentation, problem-solving and learning during small-group work. Cambridge Journal of Education, 39(1), 7-27 (2009)

7. E. M. Nussbaum, Argumentation, dialogue theory, and probability modeling: Alternative frameworks for argumentation research in education. Educational Psychologist, 46(2), 84-106 (2011)

8. C. H. Chen, H. C. She, The impact of recurrent on-line synchronous scientific argumentation on students' argumentation and conceptual change. Educational Technology \& Society, 15(1), 197-210 (2012)

9. F. Torun, S. Şahin. Argümantasyon temelli Sosyal Bilgiler Dersinde Öğrencilerin Argüman Düzeylerinin Belirlenmesi. Eğitim ve Bilim. 41, 186, 233-251 (2016)

10. H. Aktamış, Fen Eğitiminde Kullanılan Argümantasyon Modellerinin Değerlendirilmesi. Mehmet Akif Ersoy Üniversitesi Eğitim Fakültesi Dergisi, 35, $136-172(2015)$

11. F. Marton, R. Saljö, On qualitative differences in learning I: -Outcome \& process. British Journal of Educational Psychology, 46, 4-11 (1976)

12. Ş. Beşoluk, İ. Önder, Öğretmen adaylarının öğrenme yaklaşımları, öğrenme stilleri ve eleştirel düşünme eğilimlerinin incelenmesi. Elementary Education Online, 9(2), 679-693 (2010)

13. L. Zhang, University Students' Learning Approaches in Three Cultures: An Investigation of Bigg's 3P Model. The Journal of Psychology, 134, 1, 37-55 (2000) 
14. A. M. Ellez, G. S. Sezgin, Öğretmen Adaylarının Öğrenme Yaklaşımları. V. Ulusal Fen Bilimleri ve Matematik Eğitimi Kongresi. (16-18 Eylül). Ankara:Orta Doğu Teknik Üniversitesi (2002)

15. G. Selcuk, S. Calıskan, M. Erol, Evaluation of Learning Approaches for Prospective Physics Teachers. The Journal Of Gazi Educational Faculty, 27, 2, 2541 (2007)

16. A. Choi, A study of student written argument using the Science Writing Heuristic approach in inquiry-based freshman general chemistry laboratory classes. Unpublished doctoral dissertation. University of Iowa, Iowa City, IA. (2008)

17. N. Duban, İlköğretim fen öğretiminde niçin sorgulamaya dayalı öğrenme? In 8th International Educational Technology Conference (IETC 2008) Proceedings (pp. 802-805) (2008)

18. E. Köse, A. Şahin, Yükseköğrenime yeni başlayan öğrencilerin düşüncelerini yazılı olarak ifade edebilme becerilerinin değerlendirilmesi. Milli Eğitim Dergisi, 180, 227-237 (2008)

19. N. J. Entwistle, P. Ramsden, Understanding student learning. London: CroomHelm

20. Prosser, M. \& Millar, R. The how and what of learning physics. European Journal of Psychology of Education, 4, 513-528 (1983)

21. K. Trigwell, M. Prosser, Relating approaches to study and the quality of learning outcomes at the course level. British Journal of Educational Psychology, 61, 265275 (1991)

22. E.J. van Rossum, S. M. Schenk, The relationship between learning conception, study strategy and learning outcome. British Journal of Educational Psychology, 54, 73-83 (1984)

23. S. Mayya, A.K. Rao, K. Ramnarayan, Learning approaches, learning difficulties and academic performance of undergraduate students of physiotherapy. The Internet Journal of Allied Health Sciences and Practice, 2(4), 1-6 (2004)

24. P.K. Murphy, P.A. Alexander, What counts? The predictive power of subjectmatter knowledge, strategic processing and interest in domain-specific performance. The Journal of Experimental Education, 70(3), 197-214 (2002)

25. E. Coskun, E.N. Tiryaki, Writing Skills of University Students on Argumentative Text. H. U. Journal of Education, 28(2), 102-115 (2013)

26. G. Ünal, Ö. Ergin, Buluş yoluyla fen öğretiminin öğrencilerin akademik başarılarına, öğrenme yaklaşımlarına ve tutumlarına etkisi. Türk Fen Eğitimi Dergisi, 3(1), 36-52 (2006)

27. P. Ramsden, D. Beswick, J. Bowden, Effects of learning skills interventions on first year university students' learning. Human Learning, 5, 151-164 (1986)

28. S. P. Norris, L. M. Phillips, How literacy in its fundamental sense is central to scientific literacy. Science Education, 87(2), 224-240 (2003) 